\title{
FREQÜÊNCIA DE BIOVARES DE Ralstonia solanacearum EM DIFERENTES CULTIVARES E ÉPOCAS DE CULTIVO DE BATATA NO RIO GRANDE DO SUL
}

\author{
JOÃO L.N. MACIEL ${ }^{1}$, VALMIR DUARTE ${ }^{1}$, JOSÉ R.P. SILVEIRA ${ }^{1}$ \& SUELI T. VAN DER SAND ${ }^{2}$
}

\begin{abstract}
${ }^{1}$ Departamento de Fitossanidade, Faculdade de Agronomia, Universidade Federal do Rio Grande do Sul, Cx. Postal 776, CEP 91540-000, Porto Alegre, RS, fax: (051) 316-6016, e-mail: valmir@ufrgs.br; ${ }^{2}$ Departamento de Microbiologia, Instituto de Biociências, Universidade Federal do Rio Grande do Sul, Rua Sarmento Leite, 580, CEP 90050-170, Porto Alegre, RS, fax: (051) 316-3121
\end{abstract}

(Aceito para publicação em 14/08/2001)

Autor para correspondência: Valmir Duarte

MACIEL, J.L.N., SILVEIRA, J.R.P., VAN DER SAND, S.T. \& DUARTE, V. Frequência de biovares de Ralstonia solanacearum em diferentes cultivares e épocas de cultivo de batata no Rio Grande do Sul. Fitopatologia Brasileira 26:741-744. 2001.

\section{RESUMO}

A presença das biovares I e/ou II de Ralstonia solanacearum em uma lavoura de batatas (Solanum tuberosum) tem influência direta no sucesso das medidas adotadas para controlar a murcha bacteriana. As biovares diferem entre si em relação à agressividade, latência e sobrevivência. Assim, um experimento de campo foi conduzido em uma área naturalmente infestada em duas épocas de cultivo com os objetivos de verificar (1) a incidência de biovares I e/ou II, (2) a relação entre biovar e época de plantio e (3) a relação entre biovar e cultivar de batata. Os isolados obtidos de plantas das cultivares Achat, Baronesa, Elvira, Macaca, Monte Bonito e Trapeira foram identificados como biovar I ou II através da PCR, utilizando os oligonucleotídeos iniciadores T3A e T5A. Ambas as biovares foram encontradas na área naturalmente infestada. De 73 isolados de R. solanacearum, $94,5 \%$ foram identificados como biovar II e 5,5\% como biovar I. A biovar II foi isolada dos cultivos de primavera e de outono, independente da cultivar, mas a I apenas do cultivo de primavera e de plantas assintomáticas das cultivares Achat e Macaca. A maior população da biovar I nestas duas cultivares pode ser uma evidência da possível relação entre biovar e cultivar.

Palavras-chave adicionais: Murcha bacteriana, Solanum tuberosum, PCR

\section{ABSTRACT \\ Frequency of biovars of Ralstonia solanacearum on different cultivars and potato planting seasons in Rio Grande do Sul}

The occurrence of biovars I and/or II of Ralstonia solanacearum in a potato (Solanum tuberosum) field has direct consequences for the success of the measures adopted to control bacterial wilt. Biovars differ regarding aggressiveness, latency and survival. An experiment was conducted in a naturally infested potato field in two seasons to find (1) the incidence of biovars I and II, (2) the relationship between biovar and planting season, and (3) the relationship between biovar and potato cultivar. Bacterial isolates from potato cultivars Achat, Baronesa, Elvira, Macaca, Monte
Bonito, and Trapeira were identified as biovar I or II through PCR, using T3A and T5A primers. Both biovars I and II were found in the naturally infested field. Among 73 strains, 5.5 and $94.5 \%$ were identified as biovar I and II, respectively. Biovar II was found in the spring and in the fall, regardless of the cultivar, but biovar I only in the spring season and on symptomless plants of Achat and Macaca cultivars. The highest population of biovar I on these two cultivars may be evidence for a possible relationship between biovar and cultivar.

\section{INTRODUÇÃO}

A ocorrência da bactéria Ralstonia solanacearum (Smith) Yabuuchi et al. , agente causal da murcha bacteriana (MB), é um dos fatores mais limitantes da cultura da batata (Solanum tuberosum L.) no Brasil. De acordo com recomendações para o manejo integrado da doença, o uso de cultivares resistentes, plantio de batata semente livre do patógeno e a rotação de culturas são algumas das medidas mais importantes a serem consideradas (Takatsu \& Lopes, 1997). No entanto, o sucesso do manejo depende do conhecimento de qual biovar de $R$. solanacearum ocorre na lavoura. Tal situação decorre das diferenças que existem entre estirpes das biovares, principalmente em aspectos relacionados à agressividade, sobrevivência e latência. Estirpes da biovar I apresentam maior capacidade de sobreviver no solo e na rizosfera, principalmente devido a um número maior de espécies hospedeiras do que as da biovar II. Estirpes da biovar 
II são encontradas em locais de clima mais ameno, são normalmente mais agressivas e apresentam maior capacidade de produzir infecções latentes do que as da biovar I (Lopes, 1994).

A distribuição das duas biovares nas regiões produtoras de batata do Brasil não está completamente elucidada. A biovar II tem sido a mais comumente isolada de lavouras de batata da Região Sul do País (Lopes, 1994). No Rio Grande do Sul, supõe-se que ocorra a predominância de estirpes da biovar II devido às menores temperaturas.

A distinção das estirpes de $R$. solanacearum em cinco biovares está relacionada com a capacidade do patógeno de oxidar determinados álcoois e/ou açúcares (Gillings \& Fahy, 1993). Entretanto, as biovares podem, também, ser identificadas por PCR (Seal et al., 1992; Horita \& Tsuchiya, 2001). Outro critério bastante utilizado para diferenciar estirpes de $R$. solanacearum é sua capacidade de causar sintomas em diferentes hospedeiros, distinguindo a espécie em três raças (Buddenhagen et al., 1962). No Brasil, a doença na cultura da batata tem sido associada às biovares I (raça 1) e II (raça 3) (French et al., 1993; Lopes et al., 1998).

Assim, um experimento de campo foi conduzido em duas épocas, no município de Caxias do Sul, RS, com os objetivos de verificar a incidência de biovares I e/ou II e a relação entre biovar e época de plantio, e biovar e cultivar de batata.

\section{MATERIAL E MÉTODOS}

O experimento foi conduzido na primavera e no outono, 1997/1998, no Centro de Pesquisa de Agroindústria da Fundação Estadual de Pesquisa Agropecuária (CPA/ FEPAGRO), Distrito de Fazenda Souza, Caxias do Sul, região fisiográfica da Serra do Nordeste do Rio Grande do Sul, na latitude $29^{\circ} 07^{\prime}$ sul, na longitude $50^{\circ} 59^{\prime}$ oeste, apresentando altitude média de $760 \mathrm{~m}$. Além disso, situa-se em uma região de clima subtropical úmido, que, de acordo com a classificação de Köeppen, caracteriza-se como $\mathrm{Cfb}$. A temperatura média do mês mais frio é $11,5^{\circ} \mathrm{C}$, a média anual é $15,9^{\circ} \mathrm{C}$ e a média anual máxima $21,8^{\circ} \mathrm{C}$. A precipitação pluviométrica média anual é $1663 \mathrm{~mm}$.

\section{Delineamento e condução do experimento}

Cem tubérculos, de cada uma das cultivares de batata Achat, Baronesa, Elvira, Macaca, Monte Bonito e Trapeira foram plantados em uma área naturalmente infestada com $R$. solanacearum. Fósforo $\left(90 \mathrm{~kg} / \mathrm{ha}\right.$ de $\left.\mathrm{P}_{2} \mathrm{O}_{5}\right)$, potássio $\left(90 \mathrm{~kg} / \mathrm{ha}\right.$ de $\left.\mathrm{K}_{2} \mathrm{O}\right)$ e calcáreo $(300 \mathrm{~kg} / \mathrm{ha})$ foram incorporados durante o preparo do solo e no plantio; o nitrogênio $(60 \mathrm{~kg} / \mathrm{ha})$ foi aplicado no plantio 25 dias após. $\mathrm{O}$ delineamento experimental foi de blocos ao acaso, com dez parcelas de $1 \times 3 \mathrm{~m}$ por cultivar e dez tubérculos por parcela. Duas aplicações de fungicida $(150 \mathrm{~g}$ de chlorotalonil/100 1 de água) foram feitas aos 35 e 50 dias após o plantio. A precipitação pluviométrica acumulada até a última coleta das amostras, durante os cultivos de primavera (65 dias) e de outono (72 dias), foi de 527 e 297 $\mathrm{mm}$, respectivamente.

\section{Isolamento de Ralstonia solanacearum}

Sete plantas, preferencialmente com sintoma de murcha, de cada uma das seis cultivares, foram coletadas aos 65 e 72 dias após o plantio, nos cultivos de primavera e de outono, respectivamente. Pedaços de 3-5 cm da haste foram desinfestados através da imersão por $30 \mathrm{~s}$ em álcool $70 \%$ e hipoclorito de sódio $1 \%$, consecutivamente, e lavados em água destilada esterilizada (ADE). Em seguida, seções de 3-5 mm de espessura foram recortadas e trituradas em ADE. Com uma alça de platina, transferiu-se algumas gotas da suspensão para a superfície do meio SPA-CTT (sacarose, $20 \mathrm{~g} / 1$; peptona, $10 \mathrm{~g} / 1$; ágar, $20 \mathrm{~g} / \mathrm{l} ;+0,05 \%$ de cloreto de trifenil-tetrazólio) (Kelman, 1954), em placas de Petri. As gotas foram distribuídas na superfície do meio com o auxílio da alça e, após 24-48 h, a $28^{\circ} \mathrm{C}$, colônias fluidas com centro vermelho e bordas brancas foram transferidas para SPA e, depois de 24$48 \mathrm{~h}$, a $28^{\circ} \mathrm{C}$, submetidas ao DAS-ELISA.

\section{DAS-ELISA e teste de patogenicidade em plantas de tomateiro}

O DAS-ELISA indireto seguiu o protocolo proposto pelo Centro Internacional de La Papa (CIP, 1990) e foi realizado utilizando anti-soro policlonal reativo contra $R$. solanacearum, produzido pelo CPACT-EMBRAPA (Castro et al., 1993). Isolados com reação positiva contra o anti-soro foram inoculados em plantas de tomateiro (Lycopersicon esculentum Mill.). Suspensões de células, de cada um dos diferentes isolados obtidos, com 24-48 h em meio SPA, em tampão fosfato $\left(\mathrm{K}_{2} \mathrm{HPO}_{4}, 1,13 \mathrm{~g} / 1 ; \mathrm{KH}_{2} \mathrm{PO}_{4}, 0,48 \mathrm{~g} / 1 ; \mathrm{pH} 7,2\right)$ foram ajustadas para $10^{6}$ a $10^{8} \mathrm{UFC} / \mathrm{ml}$ em espectrofotômetro (Beckman, DU 65). Trinta a 40 dias após o plantio das sementes de tomateiro, $1 \mathrm{ml}$ de cada suspensão foi injetado na haste principal de cada planta, $3 \mathrm{~cm}$ acima da linha do solo, com o auxílio de uma seringa hipodérmica. Plantas testemunhas foram inoculadas com solução tampão de fosfato. Os isolados obtidos durante os cultivos de primavera e de outono foram utilizados para inoculação de plantas das cultivares Santa Clara e Marmande, respectivamente. Os isolados foram mantidos em $\mathrm{ADE}$, em microtubos $(1,5 \mathrm{ml})$, $\pm 24^{\circ} \mathrm{C}$.

\section{Identificação por PCR}

Os isolados que causaram murcha em plantas de tomateiro foram submetidos à PCR utilizando os oligonucleotídeos iniciadores T3A (5'GGG GGT TCG AAT TCC CGC CGG CCC CA3') e T5A (5'AGT CCG GTG CTC TAA CCA ACT GAG3') (Seal et al., 1992). Inicialmente, os isolados de $R$. solanacearum foram cultivados em SPA por $24-48 \mathrm{~h}$ a $28^{\circ} \mathrm{C}$. Como foi feito no DAS-ELISA, da superfície do meio, com o auxílio de uma alça, células de cada isolado foram coletadas e transferidas para tubos de centrífuga $(0,5$ $\mathrm{ml}$ ) contendo $100 \mu \mathrm{l}$ de ADE. Os tubos, com as suspensões $\left(10^{8}\right.$ a $\left.10^{10} \mathrm{UFC} / \mathrm{ml}\right)$, foram mantidos em água a $95-98^{\circ} \mathrm{C}$ por 
Frequência de biovares de Ralstonia solanacearum em diferentes cultivares...

5 min. Totais de $3 \mu \mathrm{l}$ de cada amostra de cada isolado foram utilizados em PCRs realizadas em um termociclador MJ Research (tipo Minicycler TM). Cada reação (25 $\mu \mathrm{l})$ continha $1 \mathrm{X}$ tampão de PCR (10 mM Tris-Cl [pH 8,3], $50 \mathrm{mM} \mathrm{KCl,}$ 2,0 $\mathrm{mM} \mathrm{MgCl} 2,0,001 \%$ de gelatina [peso:vol], 0,05\% de Nonidet P-40 [vol:vol], 0,05\% de Tween 20 [vol/vol]), 0,2 mM (cada) dNTP, 1,25 U de polimerase AmpliTaq (Cenbiot, UFRGS), $1 \mu \mathrm{M}$ de oligonucleotídeos iniciadores e o DNA modelo (amostra). A cada volume submetido à reação foram adicionadas duas gotas de óleo mineral. A amplificação do DNA de $R$. solanacearum foi realizada através do aquecimento a $96{ }^{\circ} \mathrm{C}$ por $2 \mathrm{~min}$, para promover a desnaturação do DNA modelo e 34 ciclos a: $94{ }^{\circ} \mathrm{C}$ por $10 \mathrm{~s} ; 48^{\circ} \mathrm{C}$ por $15 \mathrm{~s}$ e 72 ${ }^{\circ} \mathrm{C}$ por $1 \mathrm{~min}$. No final, cada reação foi submetida à temperatura de $72{ }^{\circ} \mathrm{C}$ por $10 \mathrm{~min}$. Cada isolado foi submetido, no mínimo, a dois testes de PCR e os produtos foram resolvidos em géis de agarose a $1,5 \%$, contendo brometo de etídio $\left(2 \times 10^{-7} \mathrm{~g} / 1\right)$ e equilibrados em 1 X TAE $(0,04 \mathrm{M}$ Tris$\mathrm{HCl} ; 0,02 \mathrm{M}$ acetato de sódio; 0,002 M EDTA; pH 7,8). Após a eletroforese, os fragmentos amplificados foram visualizados em luz ultravioleta, a $300 \mathrm{\eta m}$, e fotografados utilizando-se filmes Polaroid (tipo 667).

\section{RESULTADOS E DISCUSSÃO}

\section{Incidência de biovares em área naturalmente infestada}

Isolados da biovar II foram obtidos de plantas das seis cultivares de batata nos cultivos de primavera e outono. Entretanto, os isolados da biovar I somente foram detectados nas cultivares Achat e Macaca e apenas no cultivo de primavera (Tabela 1). De acordo com Lopes et al. (1998), estirpes da biovar I são encontradas em regiões de clima mais quente e da biovar II em regiões de clima mais ameno, nos quais pode haver sobreposição das duas biovares. A prevalência, sem exclusividade, da biovar II foi relatada no

\section{TABELA 1 - Incidência das biovares I e/ou II de Ralstonia solanacearum em plantas de seis cultivares de batata (Solanum tuberosum). Caxias do Sul, 1997/98}

\begin{tabular}{|c|c|c|c|c|}
\hline \multirow{4}{*}{ Cultivar } & \multicolumn{4}{|c|}{ Cultivo* } \\
\hline & \multirow{2}{*}{\multicolumn{2}{|c|}{$\begin{array}{c}\text { Primavera } \\
\text { Biovar }\end{array}$}} & \multirow{2}{*}{\multicolumn{2}{|c|}{$\begin{array}{l}\text { Outono } \\
\text { Biovar }\end{array}$}} \\
\hline & & & & \\
\hline & I & II & I & II \\
\hline Achat & $2 * *$ & 5 & 0 & 7 \\
\hline Baronesa & 0 & 7 & $\mathrm{ND} * * *$ & ND \\
\hline Elvira & 0 & 7 & 0 & 7 \\
\hline Macaca & 2 & 5 & 0 & 7 \\
\hline Monte Bonito & 0 & 7 & 0 & 7 \\
\hline Trapeira & 0 & 7 & 0 & 7 \\
\hline Total & 4 & 38 & 0 & 35 \\
\hline
\end{tabular}

* Data do plantio - primavera: 08/10/97; outono: 03/03/98

**Número de plantas com biovares I e II numa amostra de sete.

***ND = Não determinado
Paraná (Lopes et al., 1993), e sua presença também foi registrada em Santa Catarina (French et al., 1993). A incidência de 90,5 e 100\% da biovar II (Tabela 1) nos cultivos de primavera e outono, respectivamente, confirma a hipótese da predominância desta biovar no RS, provavelmente devido às temperaturas mais amenas. Um levantamento da incidência das biovares I e II em lavouras das diferentes regiões produtoras de batata do RS dará maior consistência a esta evidência.

Os resultados obtidos, embora indiquem a predominância da biovar II, mostram a presença da biovar I. Este fato realça a importância da rotação de culturas prolongada também nas condições do RS, uma vez que estirpes pertencentes a essa biovar podem persistir no solo por vários anos (Hayward, 1991). Além disso, qualquer programa de melhoramento destinado à obtenção de genótipos resistentes à $\mathrm{MB}$ adequados ao plantio no RS deve selecionar resistência às duas biovares.

No cultivo de primavera, a média de temperatura, durante os dez dias que antecederam a coleta, foi de $22,1^{\circ} \mathrm{C}$, e no outono foi de $14,6^{\circ} \mathrm{C}$. Essa diferença, além de influenciar as densidades populacionais da bactéria na planta, pode ter afetado a própria ocorrência das biovares. No cultivo de outono, período de temperaturas mais baixas, plantas das cultivares Achat, Elvira e Monte Bonito não apresentaram sintomas de $\mathrm{MB}$, embora estirpes da biovar II tenham sido detectadas. A produção de batata semente em alguns municípios do RS, tais como Vacaria e Bom Jesus, próximos à Caxias do Sul, tem a possibilidade de gerar tubérculos com infecções latentes se a bactéria estiver no solo e as plantas não apresentarem sintomas, visto que as lavouras são vistoriadas com base na observação de plantas sintomáticas. O plantio destes tubérculos em locais com temperaturas mais elevadas pode significar problema com a MB.

Embora as plantas de tomateiro submetidas à inoculação não tenham sido avaliadas quanto ao grau de severidade da doença, os sintomas de murcha causados por todos os isolados foram característicos e bem definidos. A inoculação permitiu aumentar a garantia de que realmente se tratava de isolados de $R$. solanacearum, evitando a possibilidade de que a PCR amplificasse o DNA de outras espécies bacterianas e produzisse perfis inadequados e conduzisse a interpretações errôneas, uma vez que os oligonucleotídeos iniciadores utilizados são inespecíficos.

A detecção de infecções latentes de $R$. solanacearum e determinação da biovar em batata semente depende de técnicas eficientes e sensíveis. A técnica da PCR utilizada nesta pesquisa para a identificação de $R$. solanacearum deveria ser aprimorada para servir em testes de detecção. Embora o tempo da reação no termociclador seja de $2 \mathrm{~h}$, comparado com, no mínimo, $24 \mathrm{~h}$ requerido pelos testes bioquímicos, PCR, com os oligonucleotídeos iniciadores utilizados, também exige a utilização de culturas puras e novas (24-48 h) de $R$. solanacearum. No entanto, a identificação da biovar, através da presença de um fragmento de 100 pb como 
biovar I e de dois fragmentos com 100 e 200 pb como biovar II (Figura 1), mostrou-se bem precisa e confiável, quando comparada com os resultados dos testes bioquímicos. A eliminação da necessidade de isolamento em cultura pura e um aumento da sensibilidade tornariam a PCR uma ferramenta muito útil em estudos epidemiológicos.

\section{Relação entre biovar e época de plantio}

A ocorrência da biovar I durante o cultivo de primavera indica que plantios mais tardios são menos favoráveis a esta biovar. Tal situação implica que, em áreas onde sabidamente ocorre a biovar I, a data de plantio do cultivo de primavera pode ser postergada desde que não afete os outros componentes fenológicos ou de produção da cultura da batata.

\section{Relação entre biovar e cultivar}

A presença da biovar II em todas as cultivares nos dois períodos de cultivo descarta a possibilidade de uma relação preferencial entre esta biovar e alguma cultivar. A presença da biovar I apenas em plantas das cultivares Achat e Macaca é intrigante, particularmente com relação à primeira, que é conhecida pela sua resistência a MB. Mesmo que esta biovar estivesse presente nas demais cultivares em níveis indetectáveis, a maior população nestas duas cultivares é um indício da possível relação entre biovar e cultivar, e sua implicação epidemiológica deveria ser pesquisada.

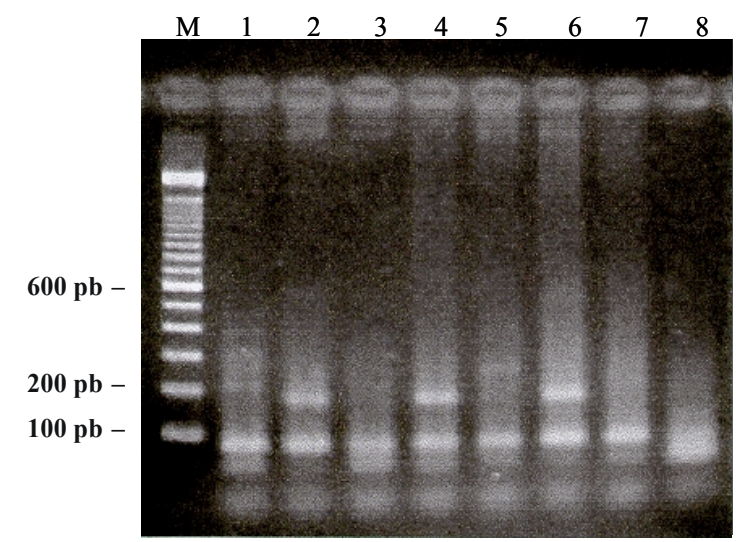

FIG. 1 - Perfil eletroforético do DNA amplificado por PCR dos isolados de Ralstonia solanacearum, utilizando os iniciadores T3A e T5A. A letra M representa o marcador de peso molecular (100 pb DNA ladder; Gibco); as linhas 1, 3, 5 e 7: isolados da biovar II; as linhas 2, 4 e 6: isolados da biovar I; e a linha 8: controle negativo.

\section{REFERÊNCIAS BIBLIOGRÁFICAS}

BUDDENHAGEN, I.W., SEQUEIRA, L. \& KELMAN, L. Designation of races in Pseudomonas solanacearum. Phytopathology 52:726. 1962. (Abstract).

CASTRO, L.A.S., DANIELS, J. \& COUTO, M.E.O. Utilização do teste de ELISA na diagnose de Pseudomonas solanacearum. Fitopatologia brasileira 18:296. 1993. (Resumo).

CENTRO INTERNACIONAL DE LA PAPA. Detección con ELISA de virus de la papa. Lima, Perú. 1990.

FRENCH, E.R., ALEY, P., TORRES, E. \& NYDEGEER, U. Diversity of Pseudomonas solanacearum in Peru and Brazil. In: Proceedings of the International Bacterial Wilt Conference. Taiwan. 1993. pp.70-77.

GILLINGS, M. \& FAHY, P. Genomic fingerprinting and PCR analysis: rapid, sensitive and inexpensive means of differentiating strains of Pseudomonas solanacearum. In: Proceedings of the International Bacterial Wilt Conference. Taiwan. 1993. pp.85-92.

HAYWARD, A.C. Biology and epidemiology of bacterial wilt caused by Pseudomonas solanacearum. Annual Review of Phytopathology 29:65-87. 1991.

HORITA, M. \& TSUCHIYA, K. Genetic diversity of japanese strains of Ralstonia solanacearum. Phytopathology 91:399-407. 2001.

KELMAN, A. The relationship of pathogenicity in Pseudomonas solanacearum to colony apperance on a tetrazolium medium. Phytopathology 44:693-695.1954.

LOPES, C.A. Brasil: Situação da murcha bacteriana da batata no Brasil. In: Memorias del Taller sobre Enfermedades Bacterianas de la Papa. Brasília. EMBRAPA/CNPH, 1994. pp.7-9.

LOPES, C.A., NAZARENO, N.R.X. \& FURIATTI, R.S. Prevalência, mas não exclusividade, da raça 3 de Pseudomonas solanacearum em batata no Estado do Paraná. Fitopatologia Brasileira 18:312. 1993. (Resumo).

LOPES, C.A., QUEZADO-SOARES, A.M., BUSO, J.A. \& MELO, P.E. Breeding for resistance to bacterial wilt of potatoes in Brazil. In: Reports of the $2^{\text {nd }}$ International Bacterial Wilt Symposium. Guadeloupe. 1998. pp.290293.

SEAL, E.S., JACKSON, L.A. \& DANIELS, M.J. Use of tRNA consensus primers to indicate subgroups of Pseudomonas solanacearum by polymerase chain reaction amplification. Applied and Environmental Microbiology 58:3759-3761. 1992.

TAKATSU, A. \& LOPES, C.A. Murcha-bacteriana em hortaliças: Avanços científicos e perspectivas de controle. Horticultura brasileira 15:170-177.1997. 